\title{
A cross-sectional study of factors underlying the risk of female nurses' suffering abuse by their partners ${ }^{1}$
}

\author{
María-Aurora Rodríguez-Borrego ${ }^{2}$ \\ Manuel Vaquero-Abellán ${ }^{3}$ \\ Liana Bertagnolli da Rosa ${ }^{4}$
}

This study aimed to identify factors underlying the risk of suffering abuse by a partner. A cross-sectional study of 622 female nurses was accomplished, randomly chosen at their place of work, at a hospital and health centers. We used a self-administered validated questionnaire that covered psychological, physical and sexual abuse, complemented by a set of sociodemographic questions. The nurses at most risk of being abused by their partners were those who supported their family by their own salary (Odds Ratio: 2.41 [0.63-9.15]), those who lived with dependents (Odds Ratio: 4.27 [1.43-2.78]) and had a partner from social class IIIa (Odds Ratio: 2.62 [1.37-5.00]). The data appear to indicate financial independence as a risk factor for this type of abuse.

Descriptors: Domestic Violence; Violence Against Women; Gender Identity; Nursing; Battered Women.

\footnotetext{
1 Paper extracted from Doctoral Dissertation "Prevalencia de violencia del compañero íntimo contra la enfermera" presented to Universidad de Córdoba, Spain. Supported by Regional Government of Andalusia, grant no: PI-0109/2008.

${ }^{2}$ RN, Antropologist, Ph.D. in Antropology, Professor, Universidad de Córdoba, Spain. E-mail: en1robom@uco.es.

${ }_{3}^{3}$ Physician, Ph.D., Professor, Universidad de Córdoba, Spain. E-mail: mvaquero@uco.es.

${ }^{4}$ Odontologist, Ph.D. in Methodology of Investigation. E-mail: lianabertagnolli@yahoo.es.
}

Corresponding Author:

María-Aurora Rodríguez-Borrego

Universidad de Córdoba. Facultad de Enfermería

Avenida Menéndez Pidal, s/n

ES 14004, Córdoba, Spain

E-mail: en1robom@uco.es 


\title{
Estudo transversal sobre fatores de risco de violência por parceiro íntimo entre enfermeiras
}

O objetivo deste estudo foi identificar os fatores de risco de abuso por parceiro íntimo entre enfermeiras. Trata-se de estudo transversal, realizado com 622 enfermeiras, selecionadas aleatoriamente nos seus locais de trabalho (hospitais e centros de saúde). Utilizou-se um questionário autoadministrado sobre maus-tratos psicológico, físico e sexual, complementado com perguntas de caráter sociodemográfico. As mulheres enfermeiras com maior probabilidade de sofrer violência foram: aquelas que mantinham a família com seu salário (Odds Ratio: 2,41 [0,63-9,15]), as que conviviam com filhos (Odds Ratio: 4,27 [1,43-2,78]) e com parceiro íntimo de classe social IIIa (Odds Ratio: $2.62[1.37-5,00])$. Os dados parecem indicar que a independência representa fator de risco para esse abuso.

Descritores: Violência Doméstica; Violência Contra a Mulher; Identidade de Gênero; Enfermagem; Mulheres Maltratadas.

\section{Estudio transversal sobre factores de riesgo de sufrir violencia por compañero íntimo en la mujer enfermera}

\begin{abstract}
Se tuvo por objetivo investigar los factores de riesgo relacionados al maltrato por compañero íntimo. Se trata de un estudio transversal realizado en 622 enfermeras, elegidas por aleatorización de sus lugares de trabajo, Hospitales y Centros de Salud. Se utilizó un cuestionario autoadministrado sobre maltratos psicológico, físico y sexual, complementado con preguntas de carácter sociodemográfico. Las mujeres enfermeras con mayor probabilidad de sufrir violencia del compañero íntimo fueron las que mantienen la familia con su salario (Odds Ratio: 2,41 [0,63-9,15]), las que conviven con hijos (Odds Ratio: 4,27 [1,43-2,78]) y las con pareja de clase social IIIa (Odds Ratio: 2.62 [1.37-5.00]). Se concluye que los datos parecen indicar que la independencia constituye un riesgo de maltrato.
\end{abstract}

Violencia Doméstica; Violencia Contra la Mujer; Identidad de Género; Enfermería; Mujeres Maltratadas.

\section{Introduction}

Intimate partner violence (IPV) occurs between two people in a close relationship. The term "intimate partner" includes current and previous spouses and dating partners. This type of violence is divided between: physical violence, sexual violence, threats and emotional abuse. Often, IPV starts with emotional abuse. This behavior can progress to physical or sexual assault. Several types of IPV may occur together ${ }^{(1)}$.

Statistics may vary from report to report, but all indicate that violence against women (VAW) has reached epidemic proportions. The World Health
Organization (WHO) Multi-Country Study of Women's Health and Domestic Violence Against Women indicates that the lifetime prevalence of IPV varies significantly by country and region, ranging from $13 \%$ to $71 \%{ }^{(2)}$. This population needs health care. According to the Centers for Disease Control and Prevention (2003), the cost of IPV against women in 1995 exceeded an estimated $\$ 5.8$ billion. This is usually considered an underestimate because the costs associated with the legal system were not included(3). 
All over the world, violence against women (VAW) has become a major social problem; it is a problem of public health and of violation of human rights. At international level, governments have promised to deal with and eliminate gender-based violence ${ }^{(4)}$. In spite of such declarations, much remains to be done; in Spain alone, we find that, in the past four years, the number of women who have died as a result of violence at the hands of their partners was 71 in 2007; in 2008, 76; in 2009, 55; in 2010, 73(5); clearly surpassing the figure for the whole of the previous year.

Nursing, a particularly female-based profession, and one whose speciality is the care of other people(6), is usually the first contact that victims of violence have with health services. Several studies have highlighted the strategic position of this profession in treating women in violent situations / relationships ${ }^{(7-8)}$.

The prominence of nurses in the health sector brings us to ask whether, as women themselves, these professionals might be suffering or have suffered VAW; in this study, we have focused on female nurses in Andalusia. From this perspective, we designed a study to identify factors affecting the risk of suffering abuse at the hands of their partner in a representative sample of Andalusian female nurses.

\section{Methods}

A cross-sectional study was performed within the sectors of specialised, primary, public and private health-care in the eight provinces of Andalusia, an autonomous region of Spain with a population of 8.3 million. Data were gathered between May and July 2008 in Córdoba, and between April and June 2009 in the other provinces. The sample population consisted of female professional nurses who were working in Andalusian institutions; single and foreign nurses were excluded from the sample.

The sample size was calculated on the basis of an expected prevalence of $12 \%$ (a rate found in all Spanish women, according to the macro-study performed in 1999 by SIGMA DOS Spain on behalf of the Women's Institute), an accuracy of $3 \%$ and a confidence level of $95 \%$. The expected losses from the sample and the very high level of respect for the privacy of the interviewees led us to hold more interviews than the minimum required sample size. In the selection of the sample, we bore in mind the following strata: centres, province, ownership of centre. To all the centres, we sent an application for permission to distribute the questionnaire, accompanied by the description of the project, the informed consent form, the questionnaire itself, the report of the Ethics Committee of the Reina Sofía University Hospital of Cordoba - Acta No156 of $01 / 30 / 2008$, and an agreement form. Finally, the questionnaire was distributed in the centres that had given us permission to do so. The sample was randomised by location in order to respect the privacy of the respondents. We attempted at all times to ensure that no respondent ever felt that she had been identified, although we are aware that the very fact that these were volunteers may well limit the generalizability of the results. The questionnaires were not collected immediately, but rather after a few days, before the collection of the sealed boxes in which the questionnaires were to be deposited, which also helped to ensure the anonymity of the women's responses.

The independent variables were classified as follows:

Sociodemographic variables: Quantitative: age of respondent, number of years together with partner, number of children and/or dependents. Qualitative: Province (Huelva, Sevilla, Jaén, Almería, Granada, Málaga, Cádiz, Córdoba), Marital status (spinster, married/stable partner, separated/divorced, widow), cohabitation (spouse/partner, children, parental family, partner's family, alone, with friends; subsequently recoded as: husband/partner, children, parental family/ partner's family, alone, husband/partner + other family members; Work-place (public, private); Work location (rural, urban); Position (staff nurse, management); Sources of family income (nursing salary, partner's salary, both salaries); Social class of partner (according to the Working Group of the Spanish Epidemiological Society ${ }^{(9)}$; Children and/or elderly (dependents).

The dependent variable was the existence of physical, psychological or sexual abuse, detected by means of a validated questionnaire ${ }^{(10)}$, which consisted of closed-response questions with five possible responses; never, almost never, sometimes, quite often, almost always. Questions 1 - 5 referred to psychological abuse; 6, 7 and 9, 10 to physical abuse, and 8 to sexual abuse (Figure 1 ). 


\begin{tabular}{|c|c|c|}
\hline \multirow{2}{*}{$\begin{array}{c}\text { Questions } \\
\text { Your husband/partner: }\end{array}$} & \multicolumn{2}{|c|}{ Abuse } \\
\hline & No & Yes \\
\hline \multirow{3}{*}{$\begin{array}{l}\text { 1. Does he respect your } \\
\text { feelings? }\end{array}$} & quite often & sometimes \\
\hline & almost always & almost never \\
\hline & & never \\
\hline \multirow{3}{*}{$\begin{array}{l}\text { 2. Has he insulted, shamed or } \\
\text { humiliated you? }\end{array}$} & never & sometimes \\
\hline & almost never & quite often \\
\hline & & almost always \\
\hline \multirow{4}{*}{$\begin{array}{l}\text { 3. Has he threatened you, your } \\
\text { children or anyone dear to you? }\end{array}$} & never & almost never \\
\hline & & sometimes \\
\hline & & quite often \\
\hline & & almost always \\
\hline \multirow{4}{*}{$\begin{array}{l}\text { 4. Has he broken any of your } \\
\text { belongings or anything in the } \\
\text { house? }\end{array}$} & never & almost never \\
\hline & & sometimes \\
\hline & & quite often \\
\hline & & almost always \\
\hline \multirow{3}{*}{$\begin{array}{l}\text { 5. Has he tried to control your } \\
\text { life or your movements? }\end{array}$} & never & sometimes \\
\hline & almost never & quite often \\
\hline & & almost always \\
\hline \multirow{4}{*}{ 6. Has he hit you? } & Never & almost never \\
\hline & & sometimes \\
\hline & & quite often \\
\hline & & almost always \\
\hline \multirow{4}{*}{ 7. Has he injured you? } & Never & almost never \\
\hline & & sometimes \\
\hline & & quite often \\
\hline & & almost always \\
\hline \multirow{4}{*}{$\begin{array}{l}\text { 8. Has he forced you to have } \\
\text { sexual relations against your } \\
\text { will? }\end{array}$} & Never & almost never \\
\hline & & sometimes \\
\hline & & quite often \\
\hline & & almost always \\
\hline \multirow{4}{*}{$\begin{array}{l}\text { 9. Has he threatened you with a } \\
\text { weapon or other object? }\end{array}$} & Never & almost never \\
\hline & & sometimes \\
\hline & & quite often \\
\hline & & almost always \\
\hline \multirow{4}{*}{$\begin{array}{l}\text { 10. Has he injured you with a } \\
\text { weapon or other object? }\end{array}$} & Never & almost never \\
\hline & & sometimes \\
\hline & & quite often \\
\hline & & almost always \\
\hline
\end{tabular}

Figure 1 - Recodification of Abuse variables according to Delgado et al. $(2006)^{(10)}$
We use the measurement scale of the questionnaire authors, although this was modified since an error in the recodification was identified(11); finally, the abuse variables were treated as dichotomies: "Yes" for the existence of abuse or "No" for its absence. The questionnaire then asked a further series of questions: $11,12,12 \mathrm{a}$ and 13 referred to subjective aspects concerning the respondent; whether she was receiving any form of professional support (e.g. psychological), and to whom she had applied for support; it also asked whether she would be willing to participate in an indepth interview, which was linked to the second part of our ongoing project "Gender-based violence inflicted on female nurses", which was qualitative in nature. The questionnaire provided the email address of the project group for respondents who accepted the offer of the indepth interview. The questionnaire was accompanied by a letter explaining the project. This was a type of informed consent that did not require the signature of the participants in the study, in order to preserve their anonymity.

The statistical analysis utilised SPSS 14.0 for Windows (SPSS Inc., Chicago, IL). The qualitative variables were expressed as absolute and relative frequencies (percentages), while the quantitative variables (both continuous and discrete) were entered as means and standard deviations. The variables were compared using Pearson's ji-square contingency tables for the qualitative and Student's t test for the quantitative variables. The significance level was set at $\mathrm{p}<0.05$.

For the estimation of risk, we used the Odds Ratio (OR), bearing in mind the variables that can operate as risk factors. We also employed logistic regression to determine the contribution of individual factors to the abuse, using the backward method of selection of variables. For each explanatory variable, we obtained the statistical significance, sign of the coefficient and OR. The OR value measures the extent to which we expect the risk of suffering abuse to change when there is a change in one variable while the others remain constant. A change close to unity indicates that no change has been caused by the variation in one unit in the variable: ORs above unity are regarded as risk factors and those less than unity is protective factors. All the variables that displayed a statistically significant association with the variable "abuse" were considered for inclusion in the "backwards" multivariate model. The variables that were not significant at the significance level of $\leq 0.05$ 
were progressively eliminated until the model was reached. The likelihood ratio test enabled us to check the null hypothesis, which was that the suppressed model variables had been correctly eliminated and that they brought no additional information to the analysis $(p=0.4)$. We then compared the scale of the continuous variable (Box-Tidwell transformation); the age of the nurse. A new variable, "BTage" was created. We used the square of this variable (Wald statistic; $p=0.517$ ) to test whether the variable plotted linearly on a logit distribution. The potential interactions and existence of confusing variables were evaluated.

\section{Results}

The prevalence of abuse among the nurses was estimated at $33 \%$, and $75.1 \%$ of the cases were of psychological abuse alone (PA), $1.5 \%$ of physical abuse alone and $2.0 \%$ of sexual abuse alone. We also found cases of combinations of types of violence; $4.9 \%$ psychological and physical, $9.3 \%$ psychological and sexual and $7.3 \%$ of all three together. Some $60.6 \%$ of the cases of abuse could be regarded as slightly serious. The nurses who participated in the study and referred to any type of abuse had the following sociodemographic profile: they were 40 years old, lived in marriage or together with a stable partner in a 20 year-long relationship, worked in an urban environment, worked as staff nurse, their family economy was based on two salaries, and they had two dependents (children or elderly relatives) (Tables $1,2,3$ ).

Table 1 - Relationship between abuse and nurses' financial support of the family $(\mathrm{N}=622)$

\begin{tabular}{|c|c|c|c|c|}
\hline \multirow{2}{*}{$\begin{array}{l}\text { Financial support of } \\
\text { family }\end{array}$} & \multicolumn{2}{|c|}{$\begin{array}{c}\text { Abuse } \\
\text { N (\%) }\end{array}$} & \multirow{2}{*}{$\mathrm{X}^{2}$} & \multirow{2}{*}{$\mathbf{p}$} \\
\hline & $\begin{array}{c}\text { No } \\
\text { (group 1) }\end{array}$ & $\begin{array}{c}\text { Yes } \\
\text { (group 2) }\end{array}$ & & \\
\hline Both salaries & 341 (82.8) & 147 (71.7) & \multirow{4}{*}{16.0} & \multirow{4}{*}{$<0.001$} \\
\hline Nurse's salary & $54(13.1)$ & $53(25.9)$ & & \\
\hline Partner's salary & $17(4.1)$ & $5(2.4)$ & & \\
\hline Total & $412(100.0)$ & $205(100.0)$ & & \\
\hline
\end{tabular}

The above values do not add up to the total due to the loss of some values. The data represent absolute frequencies (percentages). $X^{2}$ : Pearson's ji -square coefficient. p: significance level. Data collected in 2008 and 2009 ; in sectors of specialised, primary, public and private health-care in the eight provinces of Andalusia
Table 2 - Partner's social class and abuse $(\mathrm{N}=622)$. Classification of social class according to the Spanish Epidemiological Society working group ${ }^{(9)}$

\begin{tabular}{|c|c|c|c|c|}
\hline \multirow{2}{*}{$\begin{array}{l}\text { Social class of } \\
\text { partner }\end{array}$} & \multicolumn{2}{|c|}{$\begin{array}{c}\text { Abuse } \\
\text { N (\%) }\end{array}$} & \multirow[t]{2}{*}{$\mathrm{X}^{2}$} & \multirow[t]{2}{*}{$p$} \\
\hline & $\begin{array}{c}\text { No } \\
\text { (group 1) }\end{array}$ & $\begin{array}{c}\text { Yes } \\
\text { (group 2) }\end{array}$ & & \\
\hline Class I & $103(25.6)$ & $32(16.2)$ & & \\
\hline Class II & 69 (17.1) & 36 (18.3) & & \\
\hline Class IIIa & $55(13.6)$ & $33(16.8)$ & & \\
\hline Class IIIb & $93(23.1)$ & $50(25.4)$ & & \\
\hline Class IIIc & $9(2.2)$ & $3(1.5)$ & 11.1 & 0.134 \\
\hline Class IVa & 55 (13.6) & $26(13.2)$ & & \\
\hline Class IVb & $14(3.5)$ & $10(5.1)$ & & \\
\hline Class V & $5(1.2)$ & $7(3.6)$ & & \\
\hline Total & $403(100.0)$ & $197(100.0)$ & & \\
\hline
\end{tabular}

The above values may not add up to the total due to the loss of some values. The data represent absolute frequencies (percentages). $\mathrm{X}^{2}$ : Pearson's ji -squared coefficient. p: significance level.

Data collected in 2008 and 2009; in sectors of specialised, primary, public and private health-care in the eight provinces of Andalusia

Table 3 - Children and/or elderly persons supported by the nurses, and abuse (N-622)

\begin{tabular}{lccccc}
\hline & \multicolumn{3}{c}{$\begin{array}{c}\text { Abuse } \\
\text { N (\%) }\end{array}$} & & \\
Children and/or & \multicolumn{3}{c}{ X } & P \\
\cline { 2 - 3 } & No & Yes & & \\
elderly persons & (group 1) & (group 2) & & \\
\hline No & $127(30.9)$ & $46(22.5)$ & & \\
Yes & $284(69.1)$ & $158(77.5)$ & 4.7 & 0.030 \\
Total & $411(100.0)$ & $204(100.0)$ & & \\
\hline
\end{tabular}

The above values may not add up to the total due to the loss of some values. The data represent absolute frequencies (percentages). $X^{2}$ : Pearson's Chisquared coefficient. p: significance level. Data collected in 2008 and 2009; in sectors of specialised, primary, public and private health-care in the eight provinces of Andalusia

The nurses at the highest risk of being abused by their partners were those who supported their family by their own salary (Odds Ratio: 2.41 [0.63-9.15]), those who lived with dependents (OR: 4.27 [1.43-2.78]) and had a partner from social class IIIa (OR: 2.62 [1.37-5.00]) (Table 4). What the measurement of the effect is concerned, we found that the risk of suffering abuse is multiplied by 1.06 for each year of age when the other variables are held constant. For the variable "Cohabitation", the risk of suffering abuse of nurses who 
share a home with their children is 4.27 times as high as in the other categories covered by this variable, and in the case of the social class variable, the probability of suffering abuse from a partner from social class
IIa is 2.62 times as high as in the other groups. The only protective factor was the length of time spent in a relationship with the partner (OR: 0.97 [0.94-0.99]).

Table 4 - Logistic regression: univariate and multivariate analysis according to the sociodemographic characteristics of the nurses $(\mathrm{N}=569)$

\begin{tabular}{|c|c|c|c|c|}
\hline & $\mathrm{OR}^{*}(\mathrm{Cl} 95 \%)$ & $\mathbf{P}$ & $\begin{array}{l}\text { Adjusted OR } \\
\quad(\mathrm{Cl} 95 \%)\end{array}$ & $\mathbf{P}$ \\
\hline Duration of relationship with partner (years) & $0.97(0.94-1.00)$ & 0.061 & $0.97(0.94-0.99)$ & 0.032 \\
\hline Position at work & $1.05(0.59-1.89)$ & 0.849 & & \\
\hline \multicolumn{5}{|l|}{ Family financial support } \\
\hline Nurse's salary & & 0.426 & & \\
\hline Both salaries & $2.41(0.63-9.15)$ & 0.193 & & \\
\hline Partner's salary & $1.86(0.57-6.08)$ & 0.299 & & \\
\hline Dependents (Children and elderly) & $1.06(0.63-1.77)$ & 0.818 & & \\
\hline Age of nurse & $1.06(1.02-1.09)$ & 0.001 & $1.06(1.02-1.09)$ & 0.000 \\
\hline \multicolumn{5}{|l|}{ Domestic situation } \\
\hline Living alone & & 0.002 & & 0.000 \\
\hline Family or origin/partner's family & $0.63(0.20-1.97)$ & 0.429 & $0.54(0.19-1.57)$ & 0.265 \\
\hline Living with Husband/partner & $0.86(0.29-2.55)$ & 0.789 & $0.72(0.28-1.84)$ & 0.494 \\
\hline Children & $4.27(1.32-13.77)$ & 0.015 & $4.27(1.43-2.78)$ & 0.009 \\
\hline Husband + children + other family members & $1.06(0.34-3.28)$ & 0.917 & $0.90(0.34-2.35)$ & 0.837 \\
\hline \multicolumn{5}{|l|}{ Social class of partner } \\
\hline 1 & & 0.037 & & 0.027 \\
\hline II & $1.93(1.03-3.61)$ & 0.040 & $1.94(1.04-3.62)$ & 0.037 \\
\hline IIla & $2.55(1.33-4.88)$ & 0.005 & $2.62(1.37-5.00)$ & 0.003 \\
\hline III (b \& c) & $2.16(1.21-3.87)$ & 0.009 & $2.21(1.24-3.93)$ & 0.007 \\
\hline IV $(a \& b) \& V$ & $2.18(1.18-4.02)$ & 0.013 & $2.23(1.22-4.08)$ & 0.009 \\
\hline
\end{tabular}

OR: Odds ratio. ${ }^{*}$ OR: crude odds ratio obtained by univariate logistic regression. ${ }^{+}$OR: adjusted odds ratio obtained by multivariate logistic regression. Goodness of fit: Hosmer-Lemeshow statistic $=11.39, p=0.180$. CI 95\%=95-percent confidence interval. Data collected in 2008 and 2009 ; in sectors of specialised, primary, public and private health-care in the eight provinces of Andalusia

\section{Discussion}

It should be pointed out that, for many authors, VAW is a phenomenon that has its roots in the interaction among risk factors that make up the environment of the individual, the partnership, the community and society as a whole $e^{(12-15)}$. Others go more deeply into the topic of signalling that social determinants like immigration, gender inequality and the powerlessness of women in a partnership are related to $\mathrm{VAW}^{(14)}$.

In Spain, the data normally utilised are those concerning fatalities and complaints of abuse ${ }^{(5,15-17)}$. However, these data do not reflect the totality of cases of abuse. In any case, all the aspects mentioned above may lead us to underestimate the actual incidence of abuse, and for this reason all comparisons of results with those of other studies should err on the side of caution. In recent years, several studies have attempted to determine the real extent of this phenomenon, both at population level and in the health sector ${ }^{(5,18-21)}$; However, due to the lack of consensus regarding the definition of the problem and the use of different methodologies and instruments in its study, these data are difficult to compare, and it is also difficult to compare the results with the findings of other international studies.

Only Spanish nurses participated in our study. Thanks to the particular professional training they receive, a high level of education can be assumed, so the elevated incidence of abuse that we found contrasts with the above reflections. This leaves the impression that our data are closer to those of World Health Organization $(\mathrm{WHO})^{(2)}$, which suggests that greater autonomy of women at the level of education and work life threatens the traditional gender hierarchy. Other studies indicate that the rupture of traditional genderimposed patterns may aggravate violence to maintain 
this hierarchy ${ }^{(22-23)}$. Other publications, on the other hand, emphasise a high educational and occupational level as one of the most important factors in protecting women against abuse ${ }^{(24-25)}$.

This last consideration contrasts with the risk factors identified by the present study, which found that nurses who support their families by their salaries, who share their home with dependents (children and/ or elderly people) and whose partner belongs to social class IIIa (administrative personnel and management and financial support professionals, personal service and security workers) are at the highest risk of suffering violence from their partners.

Certain important limitations of the present study should be pointed out. First, it suffers all the usual biases of studies that depend on self-reference. Secondly, it is important to emphasise that VAW is a social and public health problem. Obtaining reliable, accurate and comparable data regarding the extent of violence in couples, however, poses serious methodological problems and difficulties due to a number of factors, for example the very nature of the matter of study and the heterogeneity of the measurement tools, the lack of cultural adaptation and absence of international consensus regarding the most adequate tools that would permit comparisons of the results. Furthermore, it is known that the home is where most incidents of abuse take place, being a private and intimate site which is difficult to enter for observation and study, which means that most information in this respect is derived from what people wish to make available, with all the biases and distortions this implies ${ }^{(26)}$. Thirdly, family violence is a delicate topic that is surrounded by taboos, fears, feeling of guilt and shame, which few people wish to discuss with strangers or ventilate in the public sphere. This results in a high rate of non-response and coverups that make it difficult to obtain accurate indicators of its prevalence.

\section{Conclusion}

The data that we have gathered appear to identify female financial independence as a factor that increases the risk of abuse.

\section{Acknowledgements}

We thank all the nurses who volunteered to participate anonymously in this study.

\section{References}

1. National Center for Injury Prevention and Control (USA). Understanding Intimate Partner Violence [internet]. [acesso 17 dez 2011]. Disponível em: http://www.cdc. gov/ViolencePrevention/pdf/IPV_Factsheet-a.pdf

2. World Health Organization - WHO. WHO Multi-country Study on Women's Health and Domestic Violence against Women: summary report of initial results on prevalence, health outcomes and women's responses. WHO 2005. [acesso 4 abr 2009]. Disponível em:

http://www.who.int/gender/violence/who_multicountry_ study/summary_report/summary_report_English2.pdf.

3. National Center for Injury Prevention and Control. Costs of Intimate Partner Violence Against Women in the United States. [Internet]. [acesso $17 \mathrm{dez} 2011$ ]. Disponivel em: http://www.cdc.gov/violenceprevention/ pdf/IPVBook-a.pdf

4. Lemaitre EA, Apaza RM, Silva JR. Violencia Contra la Mujer en la pareja: respuestas de la salud pública en El Alto, Bolivia. Santiago de Chile: Naciones Unidas; 2007. CEPAL - Serie Mujer y desarrollo no 84.

5. Instituto de la Mujer. Estadísticas [Internet]. Madrid: 2011 [acesso 07 ago 2011]. Disponivem em: http:// www.inmujer.es/ss/Satellite.

6. Lunardi VL. Relacionando enfermagem, gênero e formação disciplinar. Rev Bras Enferm. 1993;46(3/4):286-95.

7. Schraiber LB, D'Oliveira AFPL, França I Junior, Strake SS, Oliveira EA. A violência contra mulheres: demandas espontâneas e busca ativa em unidad básica de saúde. Saúde Soc. 2000;9:3-15.

8. Schoening AM, Greenwood JL, McNichols JA, Heermann JA, Agrawal. Effect of an Intimate Partner Violence Educational Program on the Attitudes of Nurses. JOGNN. 2004;33(5):572-9.

9. Regidor E. La clasificación de clase social de goldthorpe: marco de referencia para la propuesta de medición de la clase social del grupo de trabajo de la sociedad española de epidemiología. Rev Esp Salud Pública. 2001;75:13-22.

10. Delgado A, Aguar M, Castellano M, Luna del Castillo JD. Validación de una escala para la medición de los malos tratos a mujeres. Rev Atención Primaria. 2006;38(2):82-9.

11. Rodríguez-Borrego $M A$, Vaquero-Abellán $M$, Bertagnolli L, Redondo-Pedraza R, Muñoz-Alonso A. Error en la interpretación de un cuestionario de malos tratos. Rev Atención Primaria. 2009;41(11):650. 
12. Heise L. Violence against women: an integrated, ecological framework. Violence Against Women. 1998;4(3):262-90.

13. Vives-Cases C, Álvarez-Dardet C, Gil-Gonzáles D, Torrubiano-Domínguez J, Rohlfs I, Escribà-Agüir V. Perfil sociodemográfico de las mujeres afectadas por violencia del compañero íntimo en España. Rev Gac Sanit. 2009;23(5):410-4.

14. Morash M, Bui $H$, Zhang $Y$, Holtfreter K. Risk factors for abusive relationship: a study of Vietmamese American immigrant women. Violence Against Women. 2007;13:653-75.

15. Vives-Cases C, Torrubiano-Domínguez, ÁlvarezDardet C. Distribución temporal de las denuncias y muertes por violencia de género en España en el periodo de 1998-2006. Rev Esp Salud Pública. 2008;82:91-100. 16. Rodríguez-Borrego MA, Vaquero Abellán $M$, Bertagnolli da Rosa $L$, Redondo-Pedraza R, MuñozAlonso A. La violencia contra las mujeres en la pareja. Primeros resultados de un estudio en Andalucía. Rev Enferm Global. [Internet]. 2011;(21). [acesso 13 jan 2011]. Disponível em: http://scielo.isciii.es/pdf/eg/ v10n21/clinica1.pdf

17. Rodríguez-Borrego MA, Vaquero Abellán $M$, Bertagnolli da Rosa, L, Muñoz-Gomariz E, RedondoPedraza R, Muñoz-Alonso A. Violencia del compañero íntimo: estudio con profesionales de enfermería. Rev Atención Primaria. 2011;43(8):417-25.

18. González Méndez R, Santana Hernández JD. La violencia en parejas jóvenes. Psicothema. 2001;13(1):127-31.

19. Medina-Ariza J, Barberet R. Intimate Partner Violence in Spain. Findings from a National Survey. Violence Against Women. 2003;9(3):302-22.

20. Fontanil Y, Ezama E, Fernández R, Gil P, Herrero FJ, Paz D. Prevalencia del Maltrato de Pareja contra las Mujeres. Psicothema. 2005;17(1):90-5.

21. Ruiz-Pérez I, Mata-Pariente N, Plazaola-Castaño J. Women's Response to Intimate Partner Violence. J Interpersonal Violence. 2006;21(9):1156-68.

22. Saffioti HIB. 2004. Gênero, patriarcado, violência. São Paulo: Fundação Perseu Abramo; 2004. Coleção Brasil Urgente

23. Schraiber LB, $D^{\prime}$ oliveira AF, Portella AP, Menicucci E. Violência de gênero no campo da saúde coletiva: conquistas e desafios. Ciênc Saúde Coletiva. [periódico na Internet]. 2009; 14 (4):1019-1027 [acesso $7 \mathrm{dez}$ 2011]. Disponivel em: http://www.scielo.br/pdf/csc/ v14n4/a04v14n4.pdf
24. Gage AJ, Hutchinson, PL. Power, control and intimate partner sexual violence in Haiti. Arch Sex Behav. 2006;35:11-24.

25. Kishor S, Johnson K. Reproductive health and domestic violence: are the poorest women uniquely disadvantaged? Demography. 2006;43:293-307.

26. Medina JJ. Violencia contra la mujer en la pareja: Investigación comparada y situación en España. Valencia: Tirant Monografias; 2002. 